Portland State University

PDXScholar

$12-11-1979$

\title{
A Construct Validity Study for the Women Workers Scale Questionnaire
}

\author{
Gwen Simpson \\ Portland State University
}

Follow this and additional works at: https://pdxscholar.library.pdx.edu/open_access_etds

Part of the Psychology Commons, Women's Studies Commons, and the Work, Economy and Organizations Commons

Let us know how access to this document benefits you.

\section{Recommended Citation}

Simpson, Gwen, "A Construct Validity Study for the Women Workers Scale Questionnaire" (1979). Dissertations and Theses. Paper 2975.

https://doi.org/10.15760/etd.2968

This Thesis is brought to you for free and open access. It has been accepted for inclusion in Dissertations and Theses by an authorized administrator of PDXScholar. Please contact us if we can make this document more accessible: pdxscholar@pdx.edu. 
AN ABSTRACT OF THE THESIS OF Gwen Simpson for the Master of Science in Psychology presented December 11, 1979.

Title: A Construct Validity Study for the Women Workers Scale Questionnaire.

APPROVED BY MEMBERS OF THE THESIS COMMITTEE:

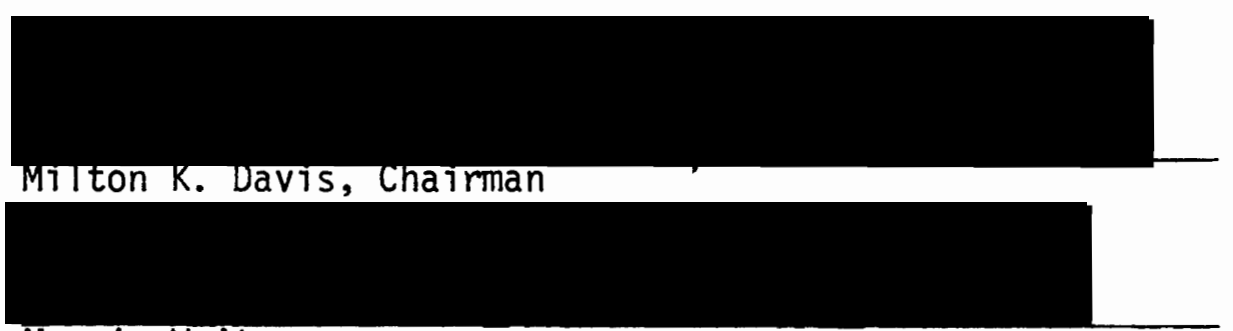

Morris Weitman

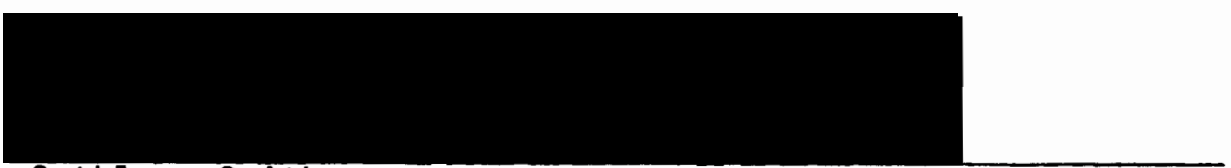

Cathleen Smith

This study attempted to obtain evidence on the construct validity of the Women Workers Scale (WWS), an attitude scale developed to measure male supervisors' attitudes toward women workers. As women enter the work world in increasing numbers, they are usually supervised by men. However, few studies have examined the attitudes of male supervisors toward women workers. At least one author (Bass, 1972) reported that there were significant differences among male managers in their attitudes toward women. Specifically, those male managers who had not worked with women held more favorable attitudes than male managers who had worked with women. 
In the present study, 30 male supervisors who had at least two men and two women employees reporting to them for six months or more volunteered to complete the necessary questionnaires. They were chosen randomly from the Portland area phone directory, and care was taken to include five different industrial areas: retail sales, general warehouses and light industries, educational and public utilities, banks and savings, and governmental agencies. Each male supervisor completed the WWS, the Attitude Toward Women Scale (AWS) and provided information on hils age. In addition, at least two men and two women who reported to him filled out a Supervisory Behavior Description Questionnaire (SBD), which provided information on the supervisor's leadership style. Two leadership style scores, Consideration (C) and Structure (S), were derived from this questionnaire.

The validation model had four components. First, a comparison was made between scores on the WWS and the AWS, with the expectation that these two attitude scales would have a positive correlation. The Pearsonian correlation of .48 was significant and supported the hypothesis that a supervisor who held a liberal attitude toward women would hold a pro-woman worker attitude. Second, a comparison of WWS scores and the female employees' mean score on the Consideration (C) subscale of the SBD was made, using the Spearman rank order correlation. A correlation of -.53 , though significant, was in the opposite direction to that predicted and did not support the hypothesis that those male supervisors who held pro-woman worker attitudes would be seen by the women employees as having a highly considerate leadership style. 
Instead, supervisors who had relatively less favorable attitudes toward women workers were seen as having more considerate leadership styles. It may be that the supervisor's consideration of women employees was based on their status as women. This consideration, or deference, may have been displayed to a greater extent by those supervisors who were ranked relatively lower on the WWS, indicating less favorable attitudes toward women workers.

The third part of the validation model compared WWS score ranks with the score ranks on the Structure $(S)$ subscale of the SBD. As predicted, a structured leadership style, as measured by the SBD (S) score rank was not related to attitude toward women workers, as measured by the WWS score rank.

The final component of the validation model compared age of the supervisor and WWS score. It was expected that older supervisors would obtain lower WWS scores. However, there was no significant correlation between age and WWS score, and thus the expectation was not supported.

In summary, the results of this study partially supported the validity of the WWS. Any further research should include a male experimenter to identify any sexual differences in the data gathering process. Because of the high reliability of the WWS $(r=.88$ in this study and .90 in an earlier study), continuing research would add to current knowledge of relationships in the work place. 
A CONSTRUCT VALIDITY STUDY FOR THE WOMEN

WORKERS SCALE QUESTIONNAIRE

\author{
by \\ GWEN SIMPSON
}

A thesis submitted in partial fulfillment of the requirements for the degree of

\author{
MASTER OF SCIENCE \\ in \\ PSYCHOLOGY
}

Portland State University 1980 
TO THE OFFICE OF GRADUATE STUDIES AND RESEARCH:

The members of the Committee approve the thesis of Gwen Simpson presented December 11, 1979.

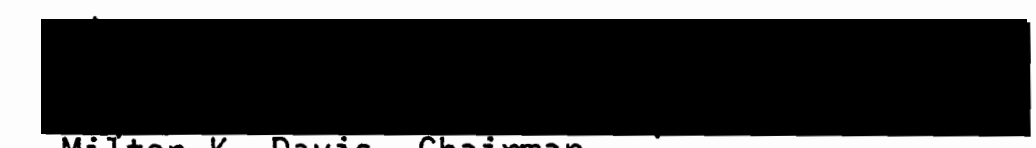

Mitton K. Davis, Chairman

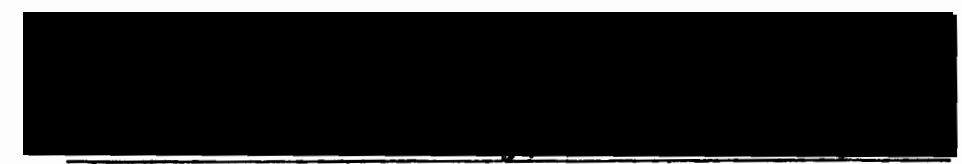

Morris Weitman

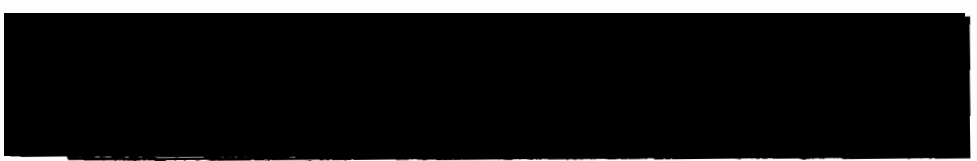

Cathleen Smith

\section{APPROVED:}

Robert E. Jones, Head, Department of Psychology

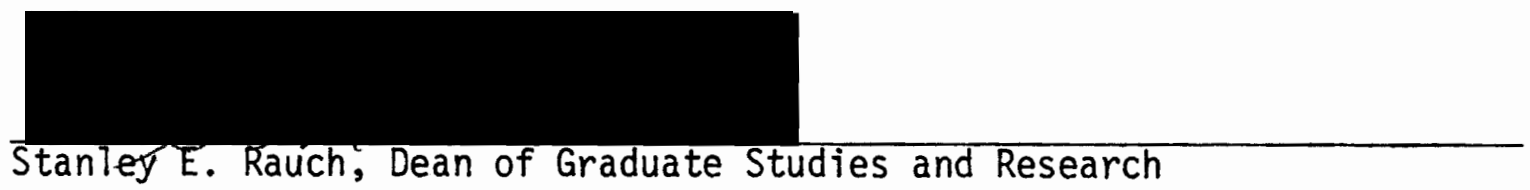




\section{ACKNOWLEDGEMENTS}

This paper would not have been possible without the cooperation of the men and women employees and their supervisors in taking time out from their jobs to complete the questionnaires. Thanks is gratefully extended to my thesis committee members, Morris Weitman, Ph. D., and Cathleen Smith, Ph. D., and to my Chairman, Milton K. Davis, Ph. D. The typist, Shirley Brown, assisted me, not only in being ready to type rough draft copies, but because of her uncomplaining cheerfulness. And for the support of my husband, Gerald Fletcher, who listened patiently to my questions and who encouraged me toward the finish of the project, I am truly grateful. 
TABLE OF CONTENTS

PAGE

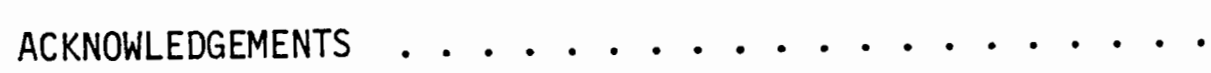

LIST OF TABLES . . . . . . . . . . . . . . . . . vi

LIST OF FIGURES ..................... vii

CHAPTER

I INTRODUCTION ................... 1

Statement of Purpose ......... . 2

Measurement of Attitude Toward Women . . 3

Women Workers Scale (WWS)

Leadership Styles .........

Age Related to Attitudes........ 11

Statement of Hypotheses ....... 12

II METHOD ...................... 15

Subjects ............ . . 15

Questionnaires.......... 16

Procedure ............ 18

III RESULTS . . . . . . . . . . . . . 21

Women Workers Scale . . . . . . 21

Attitude Toward Women Scale . . . . . 22

Supervisory Behavior Description

Questionnaire ........ 24

Age ................. 25 
CHAPTER

Comparison of Men and Women Employees

Supervisory Behavior Description

Questionnaire Scores........ 26

Summary of Findings . . . . . . . . . 27

IV DISCUSSION ........................ 28

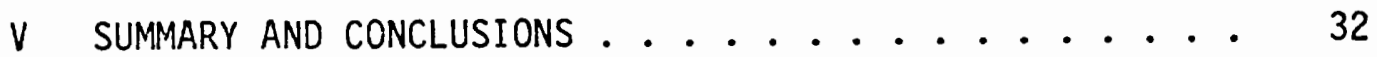

REFERENCES ............................... 34

APPENDIX A............................. 37

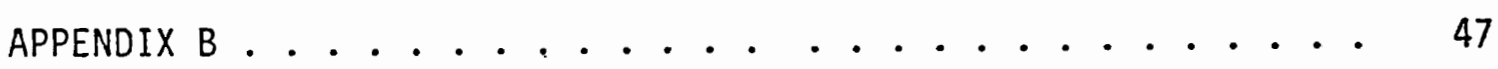

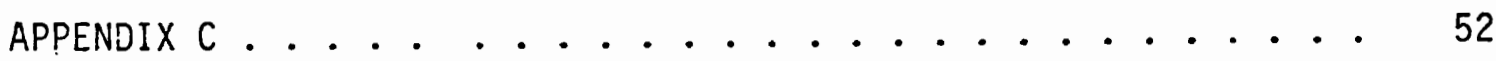




\section{LIST OF TABLES}

TABLE

PAGE

I Types of Industries Included in the Study . . . . . 16

II Distribution of WWS Scores . . . . . . . . . 21

III Distribution of AWS Scores .......... . 23

IV Distribution of Age of Supervisor . . . . . . . 26

V Summary Table of Hypotheses and Results . . . . . . 27 


\section{LIST OF FIGURES}

1. Scatter Plot of Women Workers Scale Scores and Attitude Toward Women Scale Scores......

2. Scatter Plot of Male and Female Employees Mean Scores on Supervisory Behavior Description Questionnaire Consideration Subscale....

3. Histogram of Women Workers Scale Scores and

Female Employees Mean Supervisory Behavior

Description Questionnaire Consideration

Subscale Scores ........... 55

4. Scatter Plot of Women Workers Scale and Women

Employees Average Score on the Consideration

Subscale of the Supervisory Behavior

Description Questionnaire ....... 56 


\section{CHAPTER 1}

\section{INTRODUCTION}

This study is an attempt to validate an attitude scale developed to measure male supervisors' attitudes toward women workers by relating that scale to supervisory leadership styles, general attitude toward women and age of supervisor. Topics covered are general attitudes toward women, the development of the Women Workers Scale (WWS), leadership styles and definition of the construct validation model.

Now that women are entering the work force in increasing numbers and may continue to do so for the next few years, they work and perform tasks previously done by men. They report to supervisors, the same as other workers, and these supervisors are usually men. The growing frequency of this relationship between male supervisors and women workers is a significant new aspect of the workplace and an important area of study. This researcher became interested in attitudes of supervisors toward women and whether these attitudes could be measured.

Few researchers have studied the attitude of male managers toward women, but one such study was done by Bass (1972). This study showed that male managers who had female subordinates held less favorable attitudes toward women workers than male managers who had not supervised women. The study included 174 managers' responses on seven factors which included: "Career Orientation, Supervisory Potential, Dependability, Deference, Emotionality, Capability, and Life Style." (Bass, 1972, p. 229). On five factors those managers who had not worked with women responded more favorably than managers who had worked with women. Bass concluded 
that these unfavorable attitudes may "...indicate some of the reasons why women are having difficulty achieving the equality they feel is important for them in the work situation." (Bass, 1972, p. 232).

The findings by Bass pointed to the possibility that male supervisors' attitudes toward women could be measured and a field study could be designed to compare these attitudes to attitudes of male supervisors toward men workers. The possibility of a field study was explored when the author, with the assistance of one male and one female graduate student compiled a group of items into a measure of male supervisors' attitudes toward women workers. This early research resulted in a preliminary instrument called the Women Workers Scale (WWS) which had a significant internal consistency; that is, items answered in the desired direction--pro-woman attitude--by subjects who had total scores above the median were answered in the opposite direction by subjects who had scores below the median. The important finding that male supervisors may hold varying attitudes toward women subordinates led to the decision to attempt to validate the WWS.

\section{Statement of Purpose}

A testing instrument can be useful only when there is evidence for its validity as a measure. This study used the construct validity model. Specifically, a construct is defined by Horace B. English and Ava Champney English on page 116 in A Comprehensive Dictionary of Psychological and Psychoanalytical Terms (1966) as "A property ascribed to at least two objects... a construct is a planfully designed model..." The validity of the construct is defined on page 575 of this same dictionary as: 
"...the degree to which the items collectively are representative of the whole range or class of behaviors..."

Cronbach (1955) stated that construct validity involved "defining a model or 'network' within which the construct can be theorized and the results interpretable." (Cronbach, 1955, p. 299-300).

The construct validation model adopted in the present study compared the measure of male supervisors' attitudes toward women workers with a measure, already validated, of general attitudes toward women in society. It was expected that these two measures would show a convergent relationship because of the similarity of attitude objects. A convergent relationship was also expected when the measure of attitudes toward women workers was compared with a measure of the male supervisor's considerate style of leadership. In contrast, divergent relationships were expected when the instrument measuring male supervisors' attitudes toward women workers was compared with a measure of the supervisors' structured style of leadership and the age of the supervisor.

\section{Measurement of Attitude Toward Women}

Many studies of masculinity and femininity were reviewed and found to measure personality traits (Bem, 1974) or were ratings developed in laboratory studies to identify sex differences in the decision making process (Bartol and Butterfield, 1976). Janet T. Spence and Robert Helmreich (1972) studied attitudes toward women and their roles in society. Spence and Helmreich reported a lack of an "objective, psychometrically-sound instrument" which could be used for measuring attitudes toward women in today's society (p.2). They then decided to alter an 
early scale they had researched entitled the Kirkpatrick Belief-Pattern Scale for Measuring Attitudes toward Feminism, published in 1936. This older scale provided a starting point for the development of Spence and Helmreich's Attitudes Toward Women Scale (AWS). The AWS has since been used in research studies by Loo and Logan (1977) and Lunneborg (1974), who administered it to subjects in Canada and Washington State, respectively. Results were similar for both of these studies and indicated that male subjects held significantly less liberal attitudes toward women than female subjects. For example, male subjects, as compared to female subjects, more frequently agreed that sons should be given more encouragement to go to college than daughters, and that it was ridiculous for a woman to run a locomotive and for a man to darn socks. Furthermore, these investigations showed a shorter version of the AWS could be used with reliability. Compared with the AWS questionnaire of 55 items, the short version had 25 items which identified the same three factors of traditional role in the home and marriage situation, vocational and educational areas, and sexual behavior and "etiquette." Women Workers Scale (WWS). Supported by these attitude studies (Spence and Helmreich, 1972; Bass, 1972), work continued on the preliminary development of a questionnaire to measure male supervisors' attitudes toward women workers. This measure was based on the comparison, by the supervisor, of both men and women workers. The items, as well as format, for this preliminary instrument were developed by the author and two other graduate students, one male and one female. Instead of the 5-point Likert scale used by Bass, a 6-point Likert scale was used to allow subjects a range of choices from disagreement to agreement and 
avoided a middle value. In this early work, it was decided to use the following formats for the items:

In my opinion, women workers

...like to be called by nicknames, in

fact it raises their morale.

In my opinion, women workers as compared

to men workers,

...have less motivation to get ahead.

In the initial reliability study conducted by the author, 100 male supervisors in various sales, industrial, banking and social service agencies completed the original 55-item WWS. Personnel managers of large organizations were contacted as well as neighborhood-area supervisors of small professional and retail sales offices; all subjects had supervised five women for at least six months. Because of the sensitive nature of some of the items, each supervisor was guaranteed anonymity. Very few men, less than ten, refused to complete the questionnaire, with one company official declining because his company was involved in pending court action on charges of sex discrimination at the time of the initial survey. These supervisors were contacted in person and the questionnaire was filled out immediately and returned to the experimenter. Questionnaires were scored, divided at the median score into high and low score groups; each item was analyzed by comparing the responses of the upper and lower groups. The item analysis generated phi $(\phi)$ coefficients for each of the origina1 55 items. Items with $\phi=.25$ or more were retained and the reliability coefficient calculated according to Kuder-Richardson Formula 21. The remaining 30 items had a reliability 
of .90, which indicated that the questionnaire had potential for use in measuring supervisory attitudes.

The final attitude questionnaire had 30 items which were divided into five categories:

$$
\begin{array}{ll}
\text { Dependability (4 items) } & \begin{array}{l}
\text { (sick leave, lateness) } \\
\text { (nicknames, dress code, } \\
\text { temperament) }
\end{array} \\
\text { Job Performance (7 items) } & \begin{array}{l}
\text { (neatness of work, } \\
\text { deadlines) }
\end{array} \\
\text { Promotability (3 items) } & \begin{array}{l}
\text { (future capability, } \\
\text { length-of-stay, job } \\
\text { status) } \\
\text { (gossipping, cooper- } \\
\text { ativeness) }
\end{array}
\end{array}
$$

It should be noted that the Dependability and Job Performance categories contained objective items which the supervisor could verify; i.e., the number of days absent. Items in the Promotability, Interpersonal Relations and Feminism categories called for largely subjective assessment of women workers. 
Leadership Styles

The concept that women perceive effective leadership differently from men should be examined as part of the "net work" of relations in the construct validation model. For example, men may prefer a structured style of leadership where the supervisor's role emphasizes organization and establishment of precise pattern of job duties. Women may prefer a considerate style of leadership where the supervisor's role emphasizes mutual trust, friendship, and respect.

In a study on sex-role stereotyping of leadership styles by Rosen and Jerdee (1973) significant differences were found between men and women subordinates who rated the leadership styles of supervisors. The "friendly-dependent" style of leadership was rated significantly more often when the sex of the supervisor and the subordinate were different; i.e., when the supervisor was male and the subordinates were female. Sex-role stereotyping for managers showed up in a study by Bartol and Butterfield (1976). Male and female managers' style of leadership was rated by 312 students at an eastern university. Male managers were rated higher on structured leadership style than female managers. Women managers were expected to show consideration, and not structure. The authors stated that these results may be mediated by actual on the job experiences with a particular manager.

A male supervisor's attitude toward women workers may very well differ from his attitude toward men workers. It was theorized that male supervisors would display a considerate manner toward women workers in relation to attitudes held about women workers. It was logical to as- 
sume that the male supervisor's pro-woman, or liberal, attitude should vary to the degree he displayed a considerate leadership style.

Usefulness of the relationship between a manager's leadership style and his attitude toward women workers in the construct validation model rested on the identification of a measurement of leadership styles. One such measurement was Fiedier's Least-Preferred Co-Worker Scale (LPC) (1967). The LPC's format conated 16 to 24 bi-polar adjectives (the semantic differential design), such as friendly-unfriendly, and cooperative-uncooperative. The supervisor checked a number according to the degree of friendliness or cooperativeness which best described his least preferred co-worker, either known to the supervisor at the present, or known to him from a previous job. The sum of the numbers indicated either a high - or a low - LPC score and this style related to a style of leadership defined by Fiedler:

"...a person who describes his least-preferred co-workers in a relatively favorable manner tends to be permissive, human relations-oriented, and considerate of the feelings of his men.

But a person who describes his least-preferred co-worker in an unfavorable manner--who has... a low LPC rating--tends to be managing, taskcontrolling, and less concerned with the human relations aspect of the job." (Schultz, 1970, p. 248)

Fiedler theorized that this leadership style had to be measured within the entire supervisory realm and he stated three aspects of the model: power position, leader-member relations, and task structure. The position of the supervisor was the ability of the supervisor to hire or fire, or to promote or demote workers. Leader-members relations were based on two different measures, both of which reflected either a "good" or a "bad" relationship between supervisor and workers. The task struc- 
ture was simply a judgment of the task performed, and it was either structured (step-by-step) or left undefined.

Research on Fiedler's model was reviewed by Rice (1978). In a summary of over 100 experiments, Rice concluded that there is no "standard" form of the LPC scale because of the variation of item content, instructions, and response formats. He further reported that "...the LPC scale appears to be predominately composed of items that load on a single inter-personal factor..." (Rice, 1978, p. 110).

In view of the finding that the LPC lacked a "standard" form and the need to use the LPC in conjunction with the three other aspects of Fiedler's model, this researcher decided not to use the LPC scale as a measurement of leadership style.

Another possible format for measurement of leadership style was proposed by Fleishman (1962). His Leadership Opinion Questionnaire (LOQ) was developed as a result of earlier research when he worked at the Personnel Research Board of Ohio State University in 1950. A dichotomy between a type of "people" and a type of "production" leadership style orientation was identified. These two definitions were described by Fleishman as:

Consideration (C) Reflects the extent to which an individual is likely to have job relationships with his subordinates characterized by mutual trust, respect for their ideas, consideration of their feelings, and a certain warmth between himself and them. A high score is indicate of a climate of good rapport and two-way communication. A low score indicates the individual is likely to be more impersonal in his relations with group members.

Structure (S) Reflects the extent to which an individual is likely to define and structure his own role and those of his subordinates toward goal 
attainment. A high score on this dimension characterized individuals who play a very active role in directing group activities through planning, communicating information, scheduling, criticizing, trying out new ideas, and so forth. A low score characterized individuals who are likely to be relatively inactive in giving direction in these ways. (Fleishman, 1962, p. 2)

These two leadership styles were found to be related to attitudes of workers in a study by Parker (1963), which used a revised form of the LOQ entitled Supervisory Behavior Description Questionnaire (SBD). An analysis of 1,716 questionnaires completed by employees in 80 different workgroups showed the SBD was significantly correlated with a rating scale labeled "Attitude Toward Supervisor;" that is, the attitudes of the workers varied as a function of the behavior of their supervisors. In this study both $C$ and $S$ correlated significantly with the rating scale.

Studies by Fleishman and Harris (1962) and Skinner (1969) identified significant relations between both $C$ and $S$ scores and employee turnover rate. In Fleishman and Harris' study, 57 groups of three subordinates filled out SBD questionnaires for their foremen in a production plant. Employee turnover was determined by the number of workers leaving after 11 months. The correlation, between $C$ and employee turnover rate was significant $($ eta $=-.69)$. The relationship of the $S$ score to the employee turnover rate was also significant (eta $=.63)$. This positive correlation for $S$ and negative correlation for $C$ pointed toward separate leadership styles.

Skinner's (1969) findings from questionnaires completed by 21 foremen and 64 workers in a textile firm supported the previous work by 
Fleishman, with one exception. Significant correlations of .53 and .50 were calculated between Consideration score and employee turnover rate, and between Structure score and number of grievances filed, respectively. Because both correlations were positive further assurance was needed that two distinct leadership styles were being measured. If factor analysis identified two separate leadership styles, and if research comparing the responses of men and women workers gave assurance that both perceived these leadership styles as separate, the SBD could be useful in the present construct validation study.

A more current study by Szilagyi and Sims (1974) was reviewed to verify the usefulness of the SBD with both men and women workers and to verify the separateness of the two leadership styles. In a Midwest medical center where 79 percent of the employees were women, over 1,161 SBD questionnaires were completed and the results analyzed. Factor analys is verified that Consideration and Structure were different factors of leadership style. A comparison with an early work of Fleishman's (1953) was done and congruency coefficients between the 1974 and the 1953 studies of .91 and .89 were calculated for Consideration and Structure, respectively. With this evidence of stability of the SBD over a period of 21 years, along with the high percentage of women workers in the 1974 study, it was decided to use the SBD in the present construct validation study.

Age Related to Attitudes

To complete the construct validation model an, examination of age of the supervisor as it related to attitude toward women workers was undertaken. It might be expected, for example, that older managers would 
hold less liberal attitudes toward women workers than younger managers. Verification of this negative correlation between liberal attitudes toward women and age of respondent was conducted as part of Spence and Helmreich's (1972) development of the Attitude Toward Women Scale (AWS). In their sampling of college students and their partents, it was found that older people held more conservative attitudes toward women than their student children. This significant difference applied to both the mother and the father regardiess of the sex of the student.

Thus the age of the supervisor may be an important factor in any examination of supervisory attitudes, and, it appears, especially important in a study involving attitudes toward women.

\section{Statement of Hypotheses}

The construct of male supervisors' attitudes toward women workers is very difficult to specify in the context of anticipated behaviors either on the part of the male supervisor or on the part of the woman worker. A construct validation study therefore is the first step toward providing evidence that the attitude measuring instrument can be used with some confidence. This study will examine four hypotheses postulated by the construct under investigation.

The first hypothesis stated that a relationship would exist between the WWS and the AWS, and that a maie supervisor who scored high on one attitude scale would score high on the other attitude scale. Because these attitude scales measured attitudes toward women, whether in the workplace or in socjety, it was expected that the two scale scores would show a positive correlation. 
The second hypothesis stated that male supervisors' attitudes toward women workers would vary in relationship to the degree of considerate leadership style of the supervisor as perceived by women workers. Supervisors who scored high on the WWS would be perceived by women workers as having a high degree of consideration. Thus, it was expected that a positive correlation would be found between WWS scores and Supervisory Behavior Description Questionnaire Consideration subscale SBD (C) scores for women workers.

The third hypothesis stated that the male supervisors' attitude toward women workers would have no relationship with the structured-style of the supervisors' leadership as perceived by women workers. Definitions for structured leadership identified this style of leadership to be separate from other forms of leadership and the majority of studies previously reviewed have found no overlap between structured leadership style and a considerate leadership style as measured on the SBD. It was expected that the male supervisors' WWS scores would not be correlated with the SBD (S) scores for women workers.

The fourth hypothesis concerned age of the supervisor and his attitude toward women in the work role. Evidence was presented that older people hold more conservative attitudes toward women than younger people. Because the pro-woman worker attitude represents a 1 iberal view of women in the workplace, it was expected that the older supervisors would have lower WWS scores than the younger supervisors.

In summary, the construct validation model required the generation of positive correlations between similar scales (the WWS and the AWS) and between the attitude toward women workers measure and a considerate 
supervisory style measure. In contrast to these convergent measures, two divergent relations were hypothesized. One prediction stated that the attitude toward women workers measure would not be related to the structured supervisory style measure. The second prediction stated that age of the supervisor would be negatively correlated with the attitude toward women workers measure. 


\section{CHAPTER II}

\section{METHOD}

Because this study measured male supervisors' attitudes toward women workers and the corresponding women workers' opinions of their supervisor's leadership style, a minimum of 30 work groups was decided as the sample size. Five different areas of industry and government were included in order to develop a general perspective. A minimum time of six-months on the job was set for both the supervisors and the men and women employees who reported to them. This minimum was set for two reasons: first, any time less than six months was considered too short a time for the workers and supervisor to have developed a basis for their opinions; second, many companies have a probationary period for newly hired workers ranging from one to three months, but usually less than six months. The requirement that the supervisors have at least two men reporting to them, as well as the two women workers, was due to the comparison nature of items in the Women Workers Scale (WWS) questionnaire.

\section{Subjects}

A total of 55 companies were randomly selected from the Portland phone directory. There were 25 incomplete questionnaire packets returned and 30 were completed. The incomplete packets included ten which were returned after the supervisor or personnel manager of the company decided not to continue in the study. Nine of the questionnaire packets were returned incomplete; that is, one or more of the questionnaires was missing. 
Six of the company officials did not return the questionnaires.

These 30 completed questionnaire packets represented supervisors and workers from various types of industries as illustrated in Table I.

\section{TABLE I}

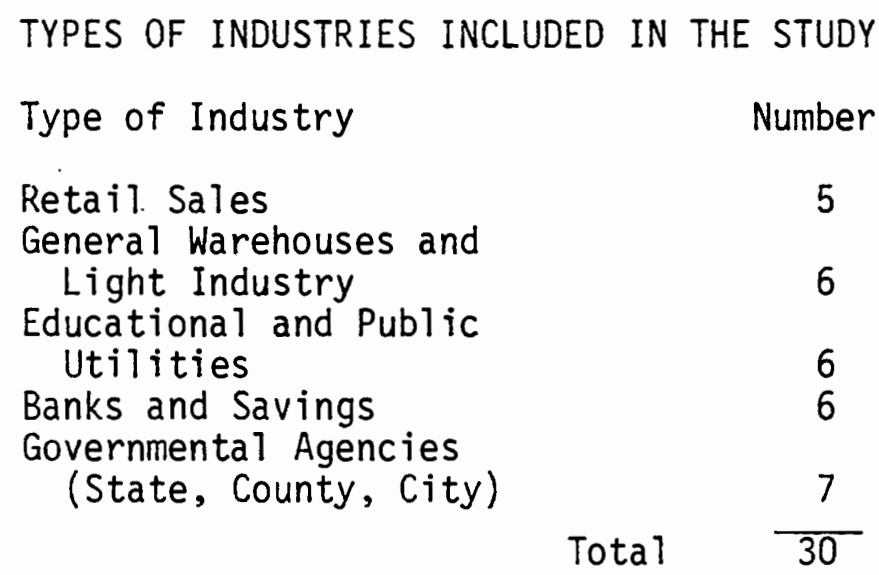

A minimum of five companies in each category were included to insure a general sampling. This stratified random sampling was chosen so that several industries and businesses would be represented. In this manner, the results did not overemphasize one area; for example, inclusion of five or six departments in one retail sales company. Because the format of the WWS included 20 items which compared both men and women workers, it had to be determined that each male supervisor had at least two men and two women subordinates who had reported to him for a minimum of six months. In addition all subjects were asked to volunteer for the study, and none of the subjects were known personally to the experimenter.

\section{Questionnaires}

The attitude questionnaire which was given to the supervisors was a combination of the Women Workers Scale (WWS) and the Attitude Toward Women Scale (AWS). The WWS contained the final 30 items from the early 
work of the author and included ten items concerning only women and 20 items comparing both men and women workers. The 25 -item short version of the AWS was used because of its proven reliability and because the shorter version saved time in administration. At the end of the supervisors' combined questionnaire the following statements were added:

I have supervised 2 men and 2 women for at least six months. Yes , No

I have been a supervisor for years.

My age is years.

For this study a packet was prepared containing the combined questionnaire for the supervisor and four copies of the Supervisory Behavior Description Questionnaire (SBD). These four copies were distributed by the supervisor to two men and two women subordinates. Each of the five questionnaires in a packet had a code number assigned for identification. This code number enables the author to match the SBD questionnaires with the supervisor's questionnaire. In addition to the code number, the only other identification were the words "male employee" or "female employee" at the top of the questionnaire. No names were required on any of the questionnaires. Envelopes were addressed to the author and were provided for each questionnaire in the packet. In this way, the subject, supervisor or worker could put the completed questionnaire into the envelope, seal it, and be assured that the responses would be confidential. An informed consent form was enclosed with each worker and supervisor questionnaire. This consent form identified the purpose of the experiment and assured the person that his/her participation in the study was voluntary. If he or she chose not to take part in the experiment, it would 
not jeopardize his or her relationship with the university.

\section{Procedure}

The experimenter contacted the personnel or the branch manager by phone and identified herself; then she briefly described the data-gathering purpose of the study, and asked if the manager would like to be part of the research study. If he agreed, inquiry was made to determine if he had supervised a minimum of two men and two women for at least six months.

If all requirements were met by the supervisor--voluntary consent, supervision of a mixed-work group, and supervision of each worker for at least six months--a time was set for the author to leave the questionnaire packet at the company. When the packet was left, there were five envelopes included so that the supervisor could put his completed questionnaire into the envelope, seal it, and return it in the mail or have the author return and pick up his completed questionnaire. The same procedure was followed for all employees' questionnaires. Out of the 30 companies, only three officials returned questionnaires by mail; the other packets were picked up by the experimenter two or three days later. Some delays in gathering the data were experienced at this point because of incompleted questionnaire packets. If the supervisor or personnel manager was not available at the time appointed to pick up the questionnaires, the experimenter called back at a later time. After two call backs, no further attempts were made to pick up the packets. In contrast, the completed packets were ready for pick-up at the time of the first call back in over 70 percent of the cases.

Most of the supervisors chose to distribute the SBD to the workers; 
the experimenter distributed them to workers in only two companies. At least two men and two women filled out the SBD questionnaires with only three exceptions; four women completed the SBD at two of the companies, and three women workers filled out the SBD at one other company. The use of more than one male and one female workers for the same supervisor was to avoid the use of data from "chosen" or favorite employees. The experimenter noted that many supervisors would ask how long it took to answer the questionnaires (after they saw the four SBD questionnaires). When 15 minutes was indicated as the average time needed to complete the SBD, the supervisor was faced with allowing one hour of employee time for this study. He was assured that the workers could take the questionnaires and complete them on their leisure time and that the envelopes provided would permit the questionnaires to be sealed to ensure confidentiality. Assurance was given again that no names were required and no companies nor departments would be identified, In return for participating in the study, a summary of the group data--not individual data--would be sent to the supervisor upon tabulation of the completed 30 packets.

The completed questionnaire packets were scored using the WWS scoring key, the AWS scoring key outlined in the AWS author's study (Spence and Helmreich, 1972, p.18-21), and the SBD scoring key included in the test manual.

The relationship between the scores from the WWS and the AWS were scrutinized by computing the Pearson product-moment correlation coefficient. Comparing the supervisor's WWS score with the employees SBD scores consisted of pairing workers' and their supervisors' scores using the code number placed on each questionnaire. The SBD scores for Consider- 
ation (C) and Structure (S) consisted of averaged scores from at least two men and two women employees. The averages were ranked with Rank 1 representing the highest averaged score for each workgroup. It was necessary then to rank the WWS scores for comparison with the SBD (C) and (S) averaged score ranks. Instead of the Pearson product-moment coorelation statistic, the Spearman rank order correlation statistic was used for comparison of WWS score ranks with SBD (C) and (S) score ranks.

Age of the supervisor was compared to the WWS score using the Pearson product-moment correlation coefficient. Data from all five areas (WWS scores, AWS scores, SBD (C) and (S) score ranks, and age) were used to identify the degree of construct validity for the WhS questionnaire. 


\section{CHAPTER III}

\section{RESULTS}

This chapter was divided into sections which described each questionnaire group separately. A summary table for the construct validation model was added for easy reference and to facilitate interpretation.

Women Workers Scale

The range, mean, and reliability were calculated for the male supervisors' WWS scores. Out of a possible score of 30 , the lowest score obtained was two and the highest score was 29. More than two-thirds of the subjects scored above the mid-point of the scale as illustrated in Table II.

TABLE II

$\begin{array}{lcc}\text { DISTRIBUTION OF WWS SCORES } \\ \text { WWS Score } & \text { Number of } & \text { Subjects } \\ 26-30 & 7 \\ 21-25 & 8 \\ 16-20 & 8 \\ 11-15 & 4 \\ 6-10 & 2 \\ 0-5 & \text { Total } & 1 \\ & -30\end{array}$


The mean score of 19.93 was significantly higher $(p<.001)$ than the average score calculated in the early WWS study (14.7). It was also higher than the midpoint of the scale (15). The distribution and the high mean of the WWS scores pointed to an upper-range restriction of scores.

The reliability coefficient calculations used the Kuder-Richardson Formula No. 21 (Guilford, 1954, p. 381). The reliability was .88 and indicated that the scale had a strong internal consistency. Questions answered in the pro-woman direction by those subjects scoring above the median (upper group) were answered in the opposite direction by those subjects scoring below the median (lower group).

\section{Attitude Toward Women Scale}

The next step was an examination of the Attitude Toward Women Scale (AWS) scores. Each of the 25 items had a possible score ranging from zero to three points, for a total of 75 . Again, the obtained range and average were in an upper-range pattern similar to the WWS scores. The AWS scores ranged from 37 to 71 and all supervisors, except one, scored above the midpoint of the scale. The following table lists the number of subjects and the AWS score intervals: 
TABLE III

DISTRIBUTION OF AWS SCORES

AWS Score Number of Subjects

$60-72$

48-59

$36-47$

24-35

$12-23$

$0-11$
13

9

8

0

0

0

Total

30

The mean AWS score was 55.25 and was significantly higher $(p .<001)$ than the midpoint of the scale (37.5). In addition to the high value of the mean score it can be seen from Table III that the distribution of the AWS scores was severely restricted to the upper range.

The reliability for the AWS was .50 and seemed low when compared to the reliability in a study by Collins (1974). In a test-retest situation using 70 male and female subjects, a reliability of .95 was obtained.

The next calculation was the correlation between the WWS scores and the AWS scores. The Pearson product-moment correlation was .48 $(p .<.05)$ for a two-tailed test. (Figure No. 1 in Appendix $C$ presents a scatter plot of WWS and AWS scores.) This significant result supported the hypothesis that there would be a relationship between scores on the WWS and AWS, and indicated that the scales measured similar attitudes. However, the .48 coefficient accounted for only 23 percent of the variance between the two scales. 
Supervisory Behavior Description Questionnaire

Averaged scores from at least two women and two men employees were used to calculate the Consideration $(C)$ and Structure $(S)$ subscale scores on the SBD. The Spearman rank order correlation coefficient (rho) was the appropriate statistic for comparison purposes. The WWS score, the SBD (C) scores, and the SBD (S) scores were ranked, with the highest score given Rank 1. Tied scores were included in the calculations. The SBD (C) scores were averaged for women subordinates who reported to the same supervisor. These averaged scores ranged from 50.5 to 100 , with 112 as the highest possible score. Previous reports of SBD (C) scores indicated an average of 68 to 82 on (C) (Fleishman, 1972, p. 13); the present mean score was 78.74 and was well within the expected average. The standard deviation for these SBD (C) averaged scores was 11.33.

Comparison of the supervisors' WWS score ranks and the averaged SBD (C) score ranks for the women workers was complicated by the restriction of scores in the upper-range on the WWS. Ranking of the WWS scores resulted in six tied ranks involving 20 subjects; there were four tied ranks on the SBD (C) scores (representing approximately 16 female employees). The Spearman correlation coefficient (rho) comparing the WWS score ranks and the women employees SBD (c) score ranks was -.53 (p. <.01). This negative correlation was not expected and did not support the expectation that the WWS scores and the women employees SBD (C) scores would be positively correlated. Interpretation, however, is complicated by the upper-range restriction of the WWS scores. 
The next comparison for this study was between the women workers' averaged SBD Structure (S) score ranks and the male supervisors' WWS score ranks. The $(S)$ scores ranged from 14.5 to 54.5 out of a possible score of 30 . The mean of 37.97 compared satisfactorily with scores listed in the SBD Manual, which suggested that (S) scores should average 36 to 46 (Fleishman, 1972, p. 13).

The next comparison supported the expectation that structure style of leadership would have no relationship to attitude of male supervisors toward women workers. A rank order correlation of .02 between SBD (S) score rank (women employees) and WWS score rank supported the hypothes is and added credibility to the construct validity of the Women Workers Scaie.

The significant correlation of (C) score ranks with WWS score ranks and the non-significant correlation of (S) score ranks with WWS score ranks lent support to the two-factor definition of leadership styles. However, no attempt was made to identify task structure in this study and the (S) score rank was included as part of the construct validation study only.

Age

The next comparison was between age of supervisor and attitude toward women workers as measured by the WWS. The ages were grouped with the eldest first, as illustrated in Table IV. 
TABLE IV

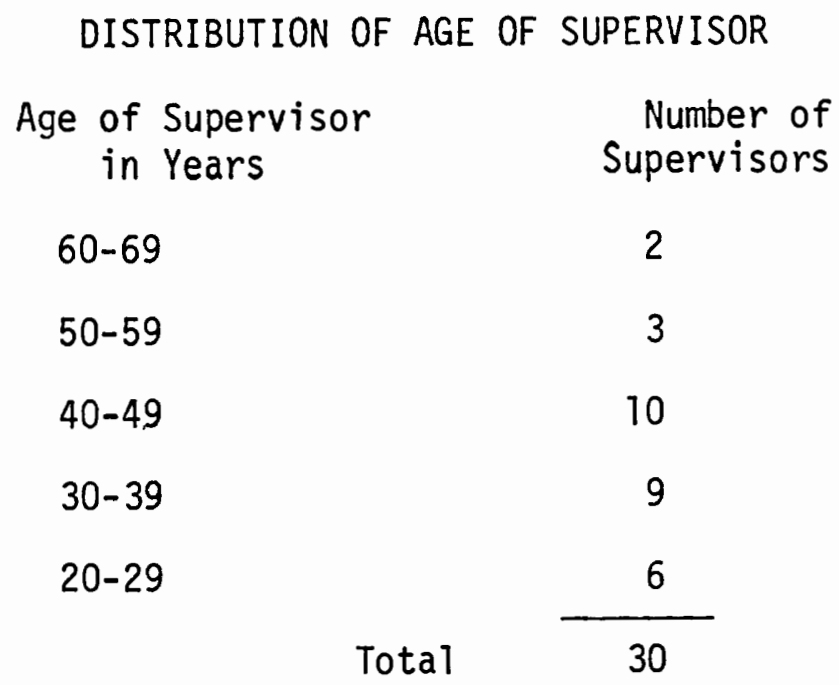

The ages ranged from 26 to 64 with a mean age of 40.13 years. Comparison of age and WWS score resulted in a non-significant correlation of .00 (Pearson product-moment correlation). This result did not support the hypothesis that age of the supervisor would be negatively correlated to his WWS score.

At this point a correiation was calculated between AWS scores and age of supervisor to determine if a relationship existed. The $\underline{r}=.00$ (Pearson correlation) and indicated no relationship between age and AWS score.

Comparison of Men and Women Employees Supervisory Behavior Description Questionnaire Scores

Although not included in the construct validation model, a comparison was made between the SBD (C) mean scores for men and women workers reporting to the same supervisor. A student's $t=-.18$ indicated that there was no significant difference between men and women worker's perception of their supervisors' considerate leadership style (Appendix $C$, Figure No. 2). A comparison of men and women workers' SBD (S) scores 
was not made because of the variety of industries sampled and because no attempt was made to insure that each of the four employees in the worksites performed the same tasks.

\section{Summary of Findings}

A summary table was compiled to list the results of this study in relation to the construct validation model. Table $V$ is a summary of the hypotheses and results.

\section{TABLE V}

SUMMARY TABLE OF HYPOTHESES AND RESULTS

Hypothes is

Results

Construct validity

1) Supervisors' WWS score

$$
r=.48(p<.05)
$$

Supported?

will be positively cor-

related with their

AWS score.

2) Supervisors' WWS score will $r_{s}=-.53(p<.01)$ Ho be positively correlated with women subordinates'

Yes

SBD (C) mean score.

3) Supervisors' WWS score will $r_{s}=.02$
not be correlated with

Yes women subordinates'

SBD (S) mean score.

4) Supervisors' WWS score will $r=.00 \quad$ No be negatively correlated with his age in years.

These results partially support the construct validity of the Women Workers Scale questionnaire. 


\section{CHAPTER IV}

\section{DISCUSSION}

As stated in the preceding chapter, only 54 percent of the delivered packets were returned in a form complete enough to use in this study. Because two-thirds of the WWS scores fell above the midpoint of the WWS scale, it appeared that those supervisors who held favorable attitudes toward women workers were more likely to return completed questionnaires than supervisors who may have held less favorable attitudes toward women workers. Further evidence for this assumption was provided by the fact that more than two-thirds of the AWS scores were above that scale's mid-point, and the scores on both scales were significantly correlated. In order to produce a greater number of low scores than the present study identified on the WWS and AWS, perhaps administering these two attitude questionnaires to male supervisors in a group setting could be done and where self-scoring and interpretation would be part of staff training. Scores elicited below the mid-points could then be analyzed to determine if the convergent relationship between the WWS and AWS still prevailed. It would also be helpful to administer the questionnaire packet to managers and employees in comparatively large organizations, 500 employees or more, and compare the results with those obtained from supervisory personnel in smaller-sized organizations. Perhaps larger companies would have male supervisors who would hold less liberal attitudes toward women 
workers than male supervisors in smaller companies. Supervisors in large organizations may also be less amenable to allowing employees the time necessary to complete the Supervisory Behavior Description Questionnaire (SBD). Allowing four workers to take time to complete the SBD could represent at least one hour of "lost" time and could result in requests from other workers to take time off for various purposes. The supervisors in smaller organizations would not have to face 20 or 30 employees who might ask questions about the study or might request time off. (The present study included various sized organizations for general test interpretation purposes.)

Results of this validity study might have been different if only production-oriented companies had been chosen. Non-production companies, or service organizations, have a milieu of "service" and cooperation which may or may not be present in production-oriented companies. For example, employees would be expected to produce or to keep the quantity of production from decreasing and every moment not working might be equated with a lessening of production quotas. In this type of workplace, where time working results in a quantifiable product, the supervisors' attitude scores on the WWS and AWS may have been lower than those in the present study. It is important to understand that some manner of selfselection of respondents did prevail, even though a mix of organizations and types of industries was maintained. Again, the reader should be reminded that the topic is highly controversial and this researcher was told at more than one company that sex-discrimination law suits were being filed or had already been adjudicated which affected them. 
Contrary to expectations, the women subordinates rated supervisors with pro-women worker attitudes as having a less considerate leadership style than supervisors who held comparatively less favorable attitudes toward women workers. An explanation for this result must lie primarily on the work-relatedness of the two measures. For example, the Consideration (C) subscale contained items which asked the subordinate to rate her supervisor on whether he was "friendly and can be easily approached," and if he "criticizes a specific act rather than a particular individual." (SBD, Items Nos. 12 and 17, Appendix B). Supervisors for whom these statements were highly descriptive held low score rankings on the WWS, indicative of relatively traditional (i.e., less favorable) attitudes toward women as workers. Perhaps these supervisors interacted with women subordinates on the basis of their status as women, displaying traditional courtesies and deferential treatment toward them. Thus, they were perceived by their women subordinates as displaying a more considerate leadership style, even though these same supervisors held less favorable attitudes toward women as workers.

These results may have been different in the presence of a bimodal distribution where both high and low scores would have been obtained on the WWS scale. It may be that male supervisors holding attitudes toward women workers which would be reflected in low WWS scores would have low SBD (C) scores. Should this pattern occur, it may indicate that the relationship between WWS and $\mathrm{SBD}(\mathrm{C})$ scores is curvilinear. Then high scores on the $\operatorname{SBD}(C)$ would correspond to midrange WWS scores. Further research involving the WWS is recommended and should attempt to obtain a large number of WWS scores below the mid-point. 
Additional attempts toward construct validation of the WWS compared the divergent measures of structured leadership style and age of supervisors with WWS scores. As expected, the structured leadership style was not correlated with the supervisors' attitudes toward women employees, a finding which supported the construct validity of the scale. However, the age of the supervisor was not, as expected, negatively correlated with his WWS score. Rather age and WWS scores were uncorrelated. That is, supervisors under 30 years of age were just as likely to score high on the WWS as supervisors over 50 years of age or just as likely to score low on the WWS. At any rate, the lack of correlation between age and WWS score did not support the hypothesis that these two items would have a negative correlation.

Further research on two levels is indicated. First, the gathering of additional data to develop norms for the WWS is essentiat. The high reliability as well as the partial support for the construct validity of the WWS have built a basic framework for additional studies, and the importance of adding to the knowledge base of valid factors in the workplace continues in our society. However, only when the validity of the WWS is developed can it be useful as an attitudinal measuring instrument.

Secondly, as the number of women workers increases, more supervisors could have the responsibility for men and women employees working together, perhaps for the first time. Supervisors who use the WWS will be able to examine their own attitudes toward women employees as compared to men employees. Research designed for pre-and post-testing could then address controversial subjects in an objective and valid manner, and identify supervisory attitudes toward men and women workers. 


\section{CHAPTER V}

\section{SUMMARY AND CONCLUSIONS}

The present study was an attempt to ascertain if there was support for the construct validity of the Women Workers Scale (WWS), an instrument designed to measure the attitude of male supervisors toward women workers. Subjects were 30 groups, each consisting of one male supervisor and at least two men and two women subordinates who reported to him. These workgroups were randomly selected from companies listed in the Portland phone book and represented five general industrial areas.

The validation model had four parts. First, a comparison was made between the WWS and a similar attitude scale, the Attitude Toward Women Scale (AWS). It was expected that the two scales would be positively correlated. This expectation was supported by the correlation of .48 between the WWS and AWS. Second, a comparison was made between the WWS score ranks and the female subordinates' mean score ranks on the Consideration (C) subscale of the Supervisory Behavior Description Questionnaire (SBD). The expectation was that these two score ranks would have a positive correlation. The correlation was significant but not in the expected direction $(-.53)$. Third, the female subordinates' mean score rank on the Structure (S) subscale of the SBD was compared with the WWS score rank. It was expected that the two ranks would not be correlated. This was supported by the results $\left(r_{s}=.02\right)$. Finally, a comparison was made between age of supervisor and WWS score, with the expectation that 
the younger the supervisor the higher he would score on the WWS. Results were not statistically significant.

The partial support for the construct validity of the WWS indicated that this instrument could be used with some confidence if succeeding research supports some of the present findings. Further validity studies should include a male experimenter for comparison of sexual differences affecting the data gathering process. A test/retest reliability study is definitely needed before company officials could use any of the results of this measurement with confidence. 


\section{REFERENCES}

Ajzen, Icek and Fishbein, Martin, "The prediction of behavior from attitudinal and normative variables." JOURNAL OF EXPERIMENTAL PSYCHOLOGY 1970, 6 (Oct) 466-487.

Anastasi, Anne, PSYCHOLOGICAL TESTING, third edition. New York: Macmillan Publishing Co., 1968.

Badin, Irwin J., "Some moderator influences on relationships between consideration, initiating structure, and organizational criteria." JOURNAL OF APPLIED PSYCHOLOGY 1974, 59 (3) 380-382.

Bartol, K. M., and Butterfield, D. A., "Sex effects in evaluating leaders:" JOURNAL OF APPLIED PSYCHOLOGY 1976, 61, 446-454.

Bass, Bernard M., et al., "Male managers attitudes toward working women." AMERICAN BEHAVIORAL SCIENTIST 1972, 221-236.

Beatty, Richard W., "Supervisory behavior related to job success of hard-core unemployed over a two-year period." JOURNAL OF APPLIED PSYCHOLOGY 1974, 59 (1) 38-42.

Bem, S. L. "The measurement of psychological androgyny." JOURNAL OF CONSULTING AND CLINICAL PSYCHOLOGY 1974, 42, 155-162.

Collins, Anne M., "The attitudes toward women scale validity, reliability, and subscore differential." DISSERTATION ABSTRACTS INTERNATIONAL 1974 (May) 34 (II-A) 7325-26.

Cronbach, L. J., and Meehi, P. E., "Construct validity in psychological tests." PSYCHOLOGICAL BULLETIN 1955, 52, 281-302.

Cummins, Robert C., "An investigation of a model of leadership effectiveness." PROCEEDINGS, 78th Annual Convention, APA 1970, 599-600.

English, Horace B., and English, Ava Champney, A COMPREHENSIVE DICTIONARY OF PSYCHOLOGICAL AND PSYCHOANALYTICAL TERMS. New York: David Mc Kay Company, Inc., 1966.

Fiedler, Fred E., "Engineer the job to fit the manager," HARVARD BUSINESS REVIEW 1965, 43, 115-122. IN Schultz, Duane P., editor, PSYCHOLOGY AND INDUSTRY, Toronto, Ontario: The MacMillan Company, Collier-MacMillan Canada, Ltd., 1970. 
Fiedler, Fred E., "The contingency model--a reply to Ashour," ORGANIZATIONAL BEHAVIOR AND HUMAN PERFORMANCE 1973, 9, 356-368.

Fleishman, Edwin A., LEADERSHIP OPINION QUESTIONNAIRE, Chicago, I11.: Science Research Associates, Inc., 1960-69.

Fleishman, E. A., and Harris, E. F., "Patterns of leadership behavior related to employee grievances and turnover." PERSONNEL PSYCHOLOGY 1962, 15, 43-56.

Fleishman, E. A., MANUAL FOR THE SUPERVISORY BEHAVIOR DESCRIPTION QUESTIONNAIRE. Washington, D.C.: American Institutes for Research, 1972.

Guilford, J. P., PSYCHOMETRIC METHODS, second edition. New York: Mc Graw-Hill Book Company, Inc., 1954.

Hsu, Chris Ching-Yang and Newton, Richard R., "Relation between foremen's leadership attitudes and the skill level of their work groups." JOURNAL OF APPLIED PSYCHOLOGY 1974, 59 (6) $771-772$.

Loo, Robert and Logan, Pamela, "Investigation of the attitudes toward women scale in western Canada." CANADIAN JOURNAL OF BEHAVIORAL SCIENCE 1977, 9 (2) 201-204.

Lunneborg, Patricia W., "Validity of attitudes toward women scale." PSYCHOLOGICAL REPORTS 1974, 34, 1281-1282.

Parker, Treadway C., "Relationships among measures of supervisory behavior, group behavior, and situational characteristics." PERSONNEL PSYCHOLOGY 1963, 16,319-334.

Rice, Robert W., "Psychometric properties of the esteem for least preferred coworker (LPC scale)." THE ACADEMY OF MANAGEMENT REVIEW 1978,3 (1), 106-118.

Rosen, Benson and Jerdee, Thomas H., "The influence of sex-role stereotypes on evaluations of male and female supervisory behavior." JOURNAL OF APPLIED PSYCHOLOGY 1973, 57 (1), 44-48.

Skinner, E., "The relationship between leadership behavior patterns and organizational-situational variables." PERSONNEL PSYCHOLOGY $1969,22,489-494$.

Spence, J. T., and Helmreich, R., "The attitudes toward women scale: an objective instrument to measure attitudes toward the rights and roles of women in contemporary society." JOURNAL SUPPLEMENT ABSTRACT SERVICE CATALOG OF SELECTED DOCUMENTS IN PSYCHOLOGY 1972, 2, 66-67. (Ms. No. 153). 
Spence, J. T., Helmreich, R., and Stapp, J., "Ratings of self and peers on sex role attributes and their relation to self-esteem and conceptions of masculinity and femininity," JOLRNAL OF PERSONALITY AND SOCIAL PSYCHOLOGY 1975, 32 (1) 29-39.

Szilagyi, Andrew D., and Sims, Henry P., Jr., "Cross-sample stability of the Supervisory Behavior Description Questionnaire," JOURNAL OF APPLIED PSYCHOLOGY 1974, 59 (6) 767-770.

U. S. Census, Bureau of the, HISTORICAL STATISTICS OF THE UNITED STATES COLONIAL TIMES TO 1970. Bicentennial Edition, Part 1.

Washington, D. C.: U. S. Government Printing Office, 1975.

U. S. Census, Bureau of the, STATISTICAL ABSTRACTS OF THE UNITED STATES. Washington, D. C.: U. S. Government Printing office, 1978.

Yunker, Gary W., "An empirical comparison of the Michigan four-factor and Ohio State LBDQ leadership scales," ORGANIZATIONAL BEHAVIOR AND HUMAN PERFORMANCE $1976,17,45-65$. 
APPENDIX A 
You are participating in a study to determine how male supervisors feel about women as workers. On the following pages you will find statements about how supervisors feel about women as workers. READ EACH STATEMENT CAREFULLY.

Decide how you feel about the area described by the statement.

--Circle 1 if you strongly agree.

--Circle 2 if you moderately agree.

--Circle 3 if you slightly agree.

--Circle 4 if you slightly disagree.

--Circle 5 if you moderately disagree.

--Circle 6 if you strongly disagree.

\section{EXAMPLE:}

In my opinion, women workers

... should be prompt and report to work within 5 minutes of their shift.

Strongly Moderately Slightly Slightly Moderately Strongly Agree Agree Agree Disagree Disagree Disagree

1

2

3

4

5

6

Answer every item.

Be frank. Give a true picture of your feelings about women as workers at the present time.

This questionnaire is confidential. No names are requested. No individual companies or departments will be identified. 
In my opinion, Strongly Moderately Slightly Slightly Moderately Strongly women workers Agree Agree

1. ...pay great attention to details in their work.

3

4

5

6

2. ...should dress

like women

by coming

to work wear-

ing dresses

and heels. 1

2

3

4

5

6

3. ...cry easily

when

corrected

concerning

their work. 1

2

3

4

5

6

4. ....are able to adjust in a short time

to changes

in the work

situation.

2

3

4

5

6

5. ...have a high

absentee

rate because

of wifely

duties.

1

2

3

4

5

6

6. ... do not get

overiy

emotional

in times of

minor crises. 1

2

3

4

5

6

7. ...like to be

called by

nicknames, in

fact, it

raises their

morale.

2

3

4

5

6 
WOMEN WORKERS SCALE (CONT.)

In my opinion, Strongly Moderately Slightly Slightly Moderately Strongly women workers Agree Agree Agree Disagree Disagree Disagree

8. ...in close

working

relationship

with men

workers, do

not cause

internal

problems on

the job. 1

2

3

4

5

6

9. ....are too

fragile and

should not

be expected

to move heavy

objects (i.e.,

over

5 ibs.) 1

2

3

4

5

6

10. ...menstrual

cycles have

major neg-

ative effects

on their

work. 1

2

3

4

5

6

In my opinion, women

workers, as compared

to men workers,

11. ...care less how their

interruptive behavior

will interfere

with the job

others are

doing.

1

2

3

4

5

6

12. ... have more

responsibilities

at home which

distract them

from

working. 1

2

3

4

5

6

13. ...are not as safety

conscious on the

job. 
WOMEN WORKERS SCALE (CONT.)

In my opinion, Strongly Moderately Slightly Slightly Moderately Strongly women workers, Agree as compared to men workers,

14. ... should be addressed by nicknames more often. 12

3

4 5

6

15. ... have less motivation to get ahead.

1

2

3

4

5

6

16. ... are more troublesome to supervise.

1

2

3

4

5 6

17. ...are more effected by their emotional state of mind, when making decisions. 1

2

3

4

5

6

18. ....are less

aggressive

and are

therefore

less likely

to provoke

anger of

their co-

workers.

1

2

3

4

5

6

19. ...have more

trouble

finishing

their

work.

1

2

3

4

5

6

20. ...doing the same job do not perform as well. 
WOMEN WORKERS SCALE (CONT.)

In my opinion, Strongly Moderately Slightly Slightly Moderately Strongly women workers, Agree Agree Agree Disagree Disagree Disagree as compared to men workers,

21. ...are more

likely to

take

company

supplies

home with

them.

1

2

3

4

6

22. ...are more

sensitive to

requests that

they not stay

on their

breaks too

long.

1

2

3

4

5

6

23. ...are more dis-

organized in

their

work.

1

2

3

4

5

6

24. ...are more

likely to

return late

from their

lunch

period.

1

2

3

4

5

6

25. ...waste more

material

doing

their job. 1

2

3

4

5

6

26. ...ask more

personal

favors of

their

super-

visors.

1

2

3

4

5

6

27. ...cannot accept

criticism of

their work

as

gracefully. 1 
WOMEN WORKERS SCALE (CONT.)

In my opinion, Strongly Moderately Slightly Slightly Moderately Strongly women workers, Agree Agree as compared to men workers,

28. ... are more disruptive in the work area because of their gossipy conversations. 1

2

3

4

5

6

29. ....are more disruptive with their laughing and talking on the job.

2

3

4

5

6

30. ...suffer more

from the stress of the job.

2

3

4

5

6

\section{ATTITUDES TOWARD WOMEN}

The statements listed below describe attitudes toward the role of women in society which different people have. There are no right or wrong answers, only opinions. You are asked to express your feelings about each statement by indicating whether you (A) Agree strongly, Agree mildly, (C) Disagree mildly or (D) Disagree strongly. Please indicate your opinion by circling the letter which corresponds to the alternative which best describes your personal attitude. Please respond to every item.

Agree Agree Disagree Disagree Strongly Mildly Mildly Strongly

1. Swearing and obscentiy is more repulsive in the speech of a woman than a man.

A $\quad$ B $\quad$ C $\quad$ D 
2. Women should take increasing responsibility for leadership in solving the intellectual and social problems of the day.

A

B

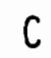

D

3. Both husband and wife should be allowed the same grounds for divorce.

A

B

C

D

4. Telling dirty jokes should be mostly a masculine perrogative.

A

5. Intoxication among women is worse than intoxication among men.

A

B

C

$D$

6. Under modern economic conditions with women being active outside the home, men should share in household tasks such as washing dishes and doing the laundry.

A

A

B

C

8. There should be a strict merit system in job appointment and promotion without regard to sex.

A

B

C

D

9. A woman should be as free as a man to propose marriage.

A

B

C

D

10. Women should worry less about their rights and more about becoming good wives and mothers.

A

B

C

$D$

11. Women earning as much as their dates should bear equally the expense when they go out together.

A

B

C

D

12. Women should assume their rightful place in business and all the professions along with men.

A B

C

13. A woman should not expect to go to exactly the same places or to have quite the same freedom of action as a man.

C 
ATTITUDES TOWARD WOMEN (CONT.)

Agree Agree Disagree Disagree

Strongly Mildly Mildiy Strongly

14. It is ridiculous for a woman to run a locomotive and for a man to darn socks.

A B $\quad$ C

D

15. In general, the father should have greater authority than the mother in the bringing up of children.

A

B

C

D

16. Women should be encouraged not to become sexually intimate with anyone before marriage, even their fiances.

B

C

D

17. The husband should not be favored by law over the wife in the disposal of family property or income.

A

B

C

D

18. Women should be concerned with their duties of childrearing and housetending, rather than with desires for professional and business careers.

A

B

C

D

19. Sons in a family should be given more encouragement to go to college than daughters.

A

B

C

D

21. Economic and social freedom is worth far more to woman than acceptance of the ideal of femininity which has been set by men.

A

B

C

D

22. On the average, women should be regarded as less capable of contribution to economic production than are men.

A

B

C

D

23. There are many jobs in which men should be given preference over women in being hired or promoted. 
ATTITUDES TOWARD WOMEN (CONT.)

\section{Agree Agree Disagree Disagree \\ Strongly Mildiy Mildly Strongly}

24. Women should be given equal

opportunity with men for

apprenticeship in the various

trades.

$\begin{array}{llll}\text { A } & \text { B } & \text { C } & \text { D }\end{array}$

25. The modern girl is entitled to

the same freedom from regulation

and control that is given to the modern boy.

A B $\quad$ C $\quad$ D

End of items.

Please fill in the blanks below.

I have supervised 2 men and 2 women for at least six months.

Yes No

I have been a supervisor for (Total) years.

My age is years.

Thank you for taking the time to be a participant in this research study. 
APPENDIX B 
by

Edwin A. Fleishman, Ph.D.

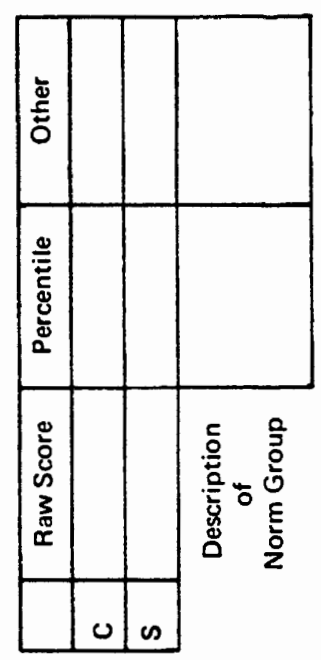

\section{INSTRUCTIONS:}

You have observed your own supervisor and probably you know pretty well how he operates. In this questionnaire, you are simply to describe some of the things your own superyisor does with your group.

For each item, choose the alternative which best describes how often your supervisor does what that item says. Remember...there are no right or wrong answers to these questions. The items simply describe the behavior of the supervisor over you; they do not judge whether his behavior is desirable or undesirable. Everyone's supervisor is different and so is every work group, so we expect differences in what different supervisors do.

Answer the items by marking an " $X$ " in the box $(a, b, c, d$ or e) next to each item to indicate your choice. 
HE IS EASY TO UNDERSTAND.
a. always
b. often
c. occasionally
d. seldom
e. never

HE ENCOURAGES OVERTIME WORK.
a. a great deal
b. fairly much
C. to some degree
d. comparatively little
e. not at all

HE TRIES OUT HIS NEW IDEAS.
a. often
b. fairly much
c. occasionally
d. once in a while
e. very seldom

a b c d e

$\square \square \square \square \square$

HE BACKS UP WHAT PEOPLE IN HIS WORK GROUP DO.
a. always
b. often
c. occasionally
d. seldom e. never

HE CRITICIZES POOR WORK.
a. always
b. often
c. occasionally
d. seldom
e. never

HE DEMANDS MORE THAN WE CAN DO.
a. often
b. fairly often
c. occasionally
d. once in a while
e. very seldom

HE REFUSES TO GIVE IN WHEN PEOPLE IN THE WORK GROUP DISAGREE WITH HIM.

a b c d e

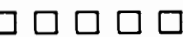

a b c d e

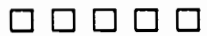

a b c d e
a. always
b. often
c. occasionally
d. seldom
e. never

HE EXPRESSES APPRECIATION WHEN ONE OF US DOES A GOOD JOB.

a b c d e
a. always
b. often
c. occasionally
d. seldom
e. never

HE INSISTS THAT PEOPLE UNDER HIM FOLLOW STANDARD WAYS OF DOING THINGS IN EVERYOETAIL.
a. always
b. often
c. occasionally
d. seldom 'e. never

HE HELPS PEOPLE IN THE WORK GROUP WITH THEIR PERSONAL PROBLEMS.

a $\quad$ b $\quad c \quad d$ e
a. often
b. fairly often
c. occasionally
d. once in a while
e. very seldom

HE IS SLOW TO ACCEPT NEW IDEAS.
a. always
b. often
c. occasionally
d. seldom
e. never

HE IS FRIENDLY AND CAN BE EASILY APPROACHED.
a. always
b. often
c. occasionally
d. seldom
e. never

HE GETS THE APPROVAL OF THE WORK GROUP ON IMPORTANT MATTERS BEFORE GOING AHEAD.
a. always
b. often
c. occasionally
d. seldom
e. never

HE RESISTS CHANGES IN WAYS OF DOING THINGS.
a. a great deal
b. fairly much
c. to some degree
d. comparatively little
e. not at all

a b c d e

HE ASSIGNS PEOPLE UNDER HIM TO PARTICULAR TASKS.
a. always
b. often
c. occasionally
d. seldom
e. never

HE STRESSES BEING AHEAD OF COMPETING WORK GROUPS.
a. a great deal
b. fairly much
c. to some degree
d. comparatively little
e. not at all

HE CRITICIZES A SPECIFIC ACT RATHER THAN A PARTICULAR INDIVIDUAL.

a b c d e

$\square \square \square \square \square$

$a$ b c d e
a. always
b. often
c. occasionally
d. seldom - e. never

a b c d e 
18. HE LETS OTHERS DO THEIR WORK THE WAY THEY THINK BEST.
a. always
b. often
c. occasionally
d. seldom
e. never

19. HE DOES PERSONAL FAVORS FOR THE PEOPLE UNDER HIM.
a. often
b. fairly often
c. occasionally
d. once in a while
e. very seldom

20. HE EMPHASIZES MEETING OF DEADLINES.
a. a great deal
b. fairly much
C. to some degree
d. comparatively little
e. not at all

21. HE SEES THAT A WORKER IS REWARDED FOR A JOB WELL DONE.
a. always
b. often
c. occasionally
d. seldom
e. never

22. HE TREATS PEOPLE UNDER HIM WITHOUT CONSIDERING THEIR FEELINGS.

a b c d e

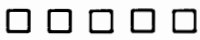

a b c d e

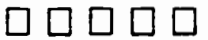

a b c d e

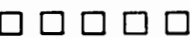

a b c d e
a. always
b. often
c. occasionally
d. once in a while
e. very seldom

23. HE INSISTS THAT HE BE INFORMED ON DECISIONS MADE BY THE PEOPLE UNDER HIM.
a. always
b. often
c. occasionally
d. seldom
e. never

24. HE OFFERS NEW APPROACHES TO PROBLEMS.
a. often
b. fairly often
c. occasionally
d. once in a while
e. very seldom

25. HE TREATS ALL WORKERS UNDER HIM AS HIS EQUALS.
a. always
b. often
c. occasionally
d. seldom
e. never

26. HE IS WILLING TO MAKE CHANGES.
a. always
b. often
c. occasionally
d. seldom
e. never

27. HE ASKS SLOWER PEOPLE TO GET MORE DONE.
a. often
b. fairly often
c. occasionally
d. once in a while
e. very seldom

28. HE CRITICIZES PEOPLE UNDER HIM IN FRONT OF OTHERS.
a. often
b. fairly often
c. occasionally
d. once in a while
e. very seldom

29. HE STRESSES THE IMPORTANCE OF HIGH MORALE AMONG THOSE UNDER HIM.
a. a great deal
b. fairly much
c. to some degree
d. comparatively little
e. not at all

30. HE TALKS ABOUT HOW MUCH SHOULD BE DONE.
a. a great deal
b. fairly much
C. to some degree
d. comparatively little
e. not at all

31. HE "RIDES" THE PERSON WHO MAKES A MISTAKE.
a. often
b. fairly often
c. occasionally
d. once in a while
e. very seldom

32. HE WAITS FOR PEOPLE UNDER HIM TO PUSH NEW IDEAS BEFORE HE DOES.
a. always
b. often
c. occasionally
d. seldom
e. never

33. HE RULES WITH AN IRON HAND.
a. always
b. often
c. occasionally
d. seldom
e. never

34. HE TRIES TO KEEP THE PEOPLE UNDER HIM IN GOOD STANDING WITH THOSE IN HIGHER AUTHORITY.
a. aiways
b. often
c. occasionally
d. seldom
e. never

a b c d e

$\square \square \square \square \square$

a b c d e

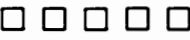

a b c d e

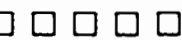

a b c d e

$\square \square \square \square \square$

a b c d e

$\square \square$

a b c d e

$\square \square \square \square \square$

a b c d e

$\square \square \square \square \square$

a b c d e

$\square \square \square \square \square$

a b c d e

$\square \square \square \square \square$

a b c d e

$\square \square \square \square \square$ 
35. HE REJECTS SUGGESTIONS FOR CHANGES.
a. always
b. often
c. occasionally
d. seldom
e. never

36. HE CHANGES THE DUTIES OF PEOPLE UNDER HIM WITHOUT FIRST TALKING IT OVER WITH THEM.
a. often
b. fairly often
c. occasionally
d. once in a while
e. very seldom

37. HE DECIDES IN DETAIL WHAT SHALL BE DONE AND HOW IT SHALL BE DONE.
a. always
b. often
c. occasionally
d. seldom e. never

a b c d e

$\square \square \square \square \square$

38. HE SEES TO IT THAT PEOPLE UNDER HIM ARE WORKING UP TO THEIR LIMITS.
a. always
b. often
c. occasionally
d. seldom
e. never

39. HE STANDS UP FOR PEOPLE UNDER HIM EVEN THOUGH IT MAKES HIM UNPOPULAR.
a. always
b. often
c. occasionally
d. seldom
e. never

40. HE MAKES THOSE UNDER HIM FEEL AT EASE WHEN TALKING WITH HIM.
a. always
b. often
c. occasionally
d. seldom e. never

41. HE PUTS SUGGESTIONS THAT ARE MADE BY THE PEOPLE UNDER HIM INTO OPERATION.
a. always
b. often
c. occasionally
d. seldom
e. never

42. HE REFUSES TO EXPLAIN HIS ACTIONS.
a. often
b. fairly often
c. occasionally
d. once in a while
e. very seldom

43. HE EMPHASIZES THE QUANTITY OF WORK.
a. a great deal
b. fairly much
c. to some degree
d. comparatively little
e. not at all

44. HE ASKS FOR SACRIFICES FROM HIS PEOPLE FOR THE GOOD OF THE ENTIRE DEPARTMENT.
a. often
b. fairly often
c. occasionally
d. once in a while
e. very seldom

45. HE ACTS WITHOUT CONSULTING THE PEOPLE UNDER HIM FIRST.
a. often
b. fairly often
c. occasionally
d. once in a while
e. very seldom

a b c d e

$\square \square \square \square \square$

46. HE "NEEDLES" PEOPLE UNDER HIM FOR GREATER EFFORT.
a. a great deal
b. fairly much
c. to some degree
d. comparatively little
e. not at all

47. HE INSISTS THAT EVERYTHING BE DONE HIS WAY.
a. always
b. often
c. occasionally
d. seldom
e. never

a b c d e

$\square \square \square \square \square$

48. HE ENCOURAGES SLOW-WORKING PEOPLE TO GREATER EFFORT.

a b c d e
a. often
b. fairly often
c. occasionally
d. once in a while
e. very seldom 
APPENDIX C 


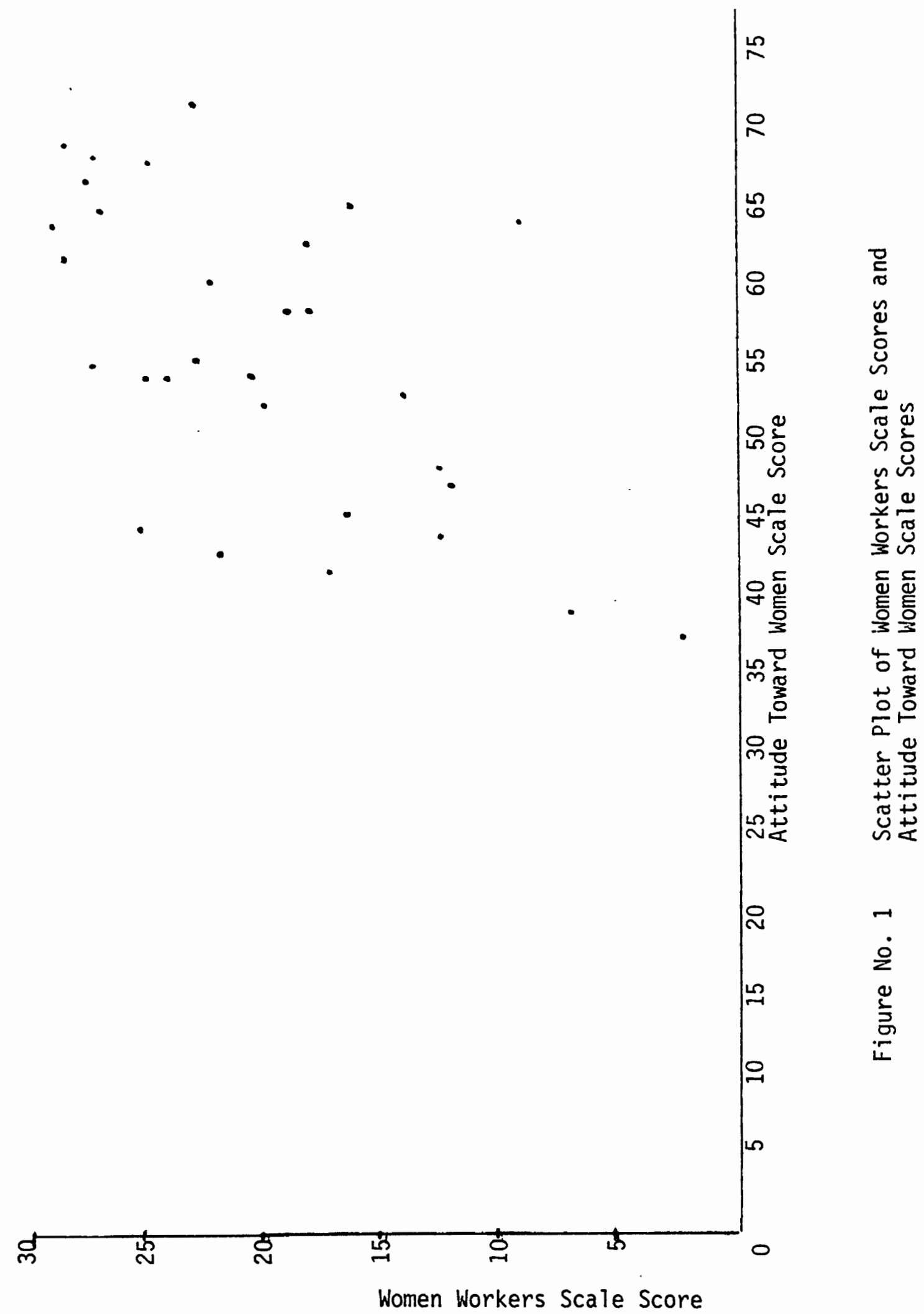




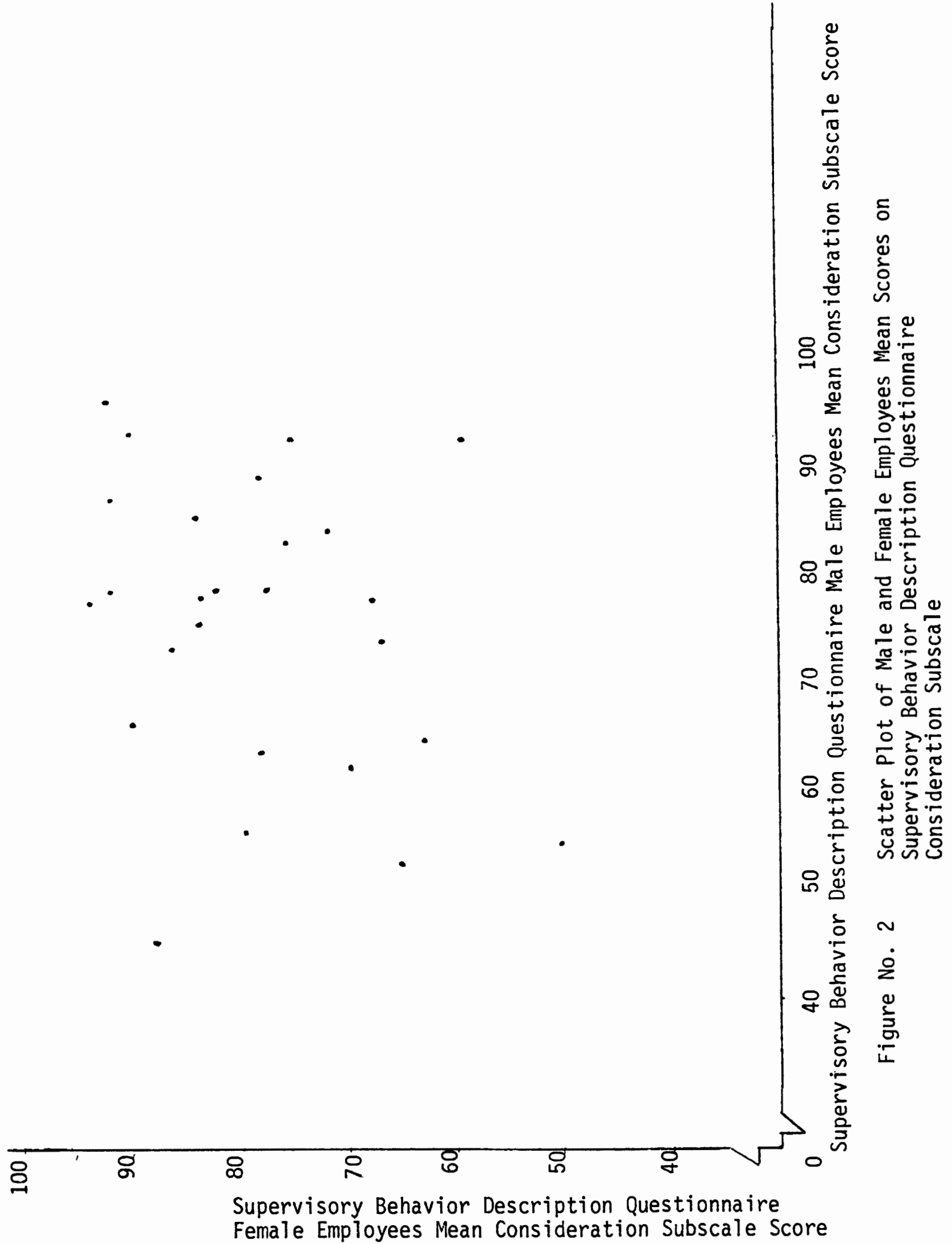




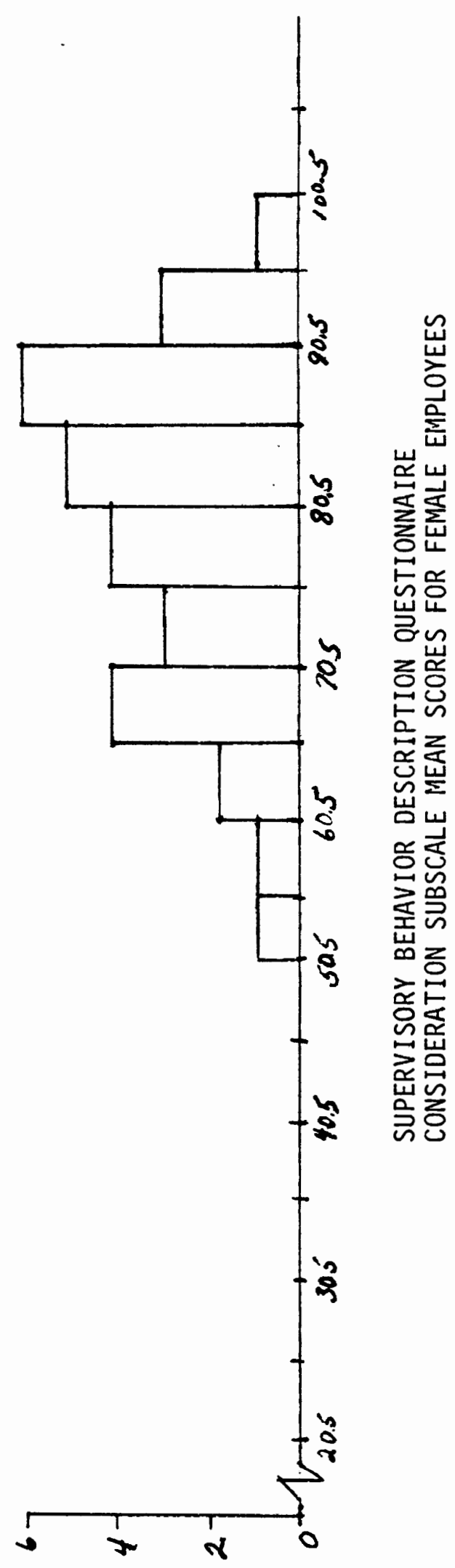

Number of Subjects

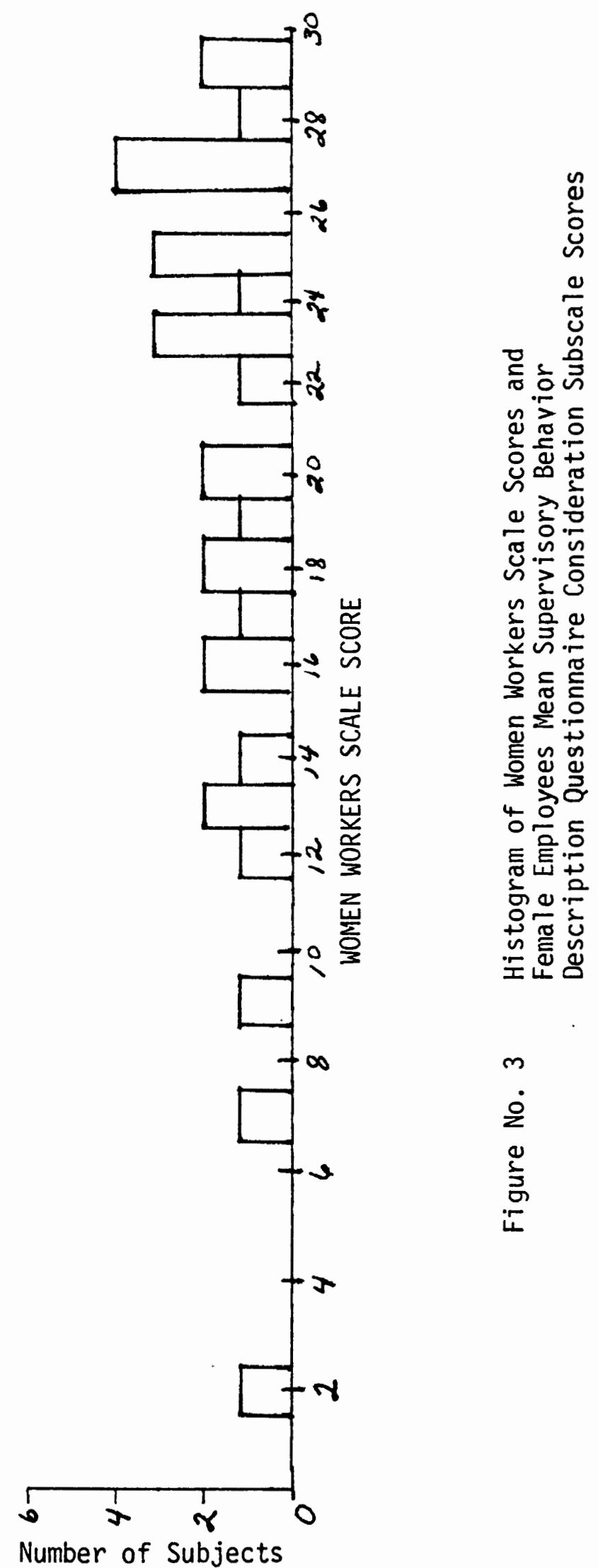




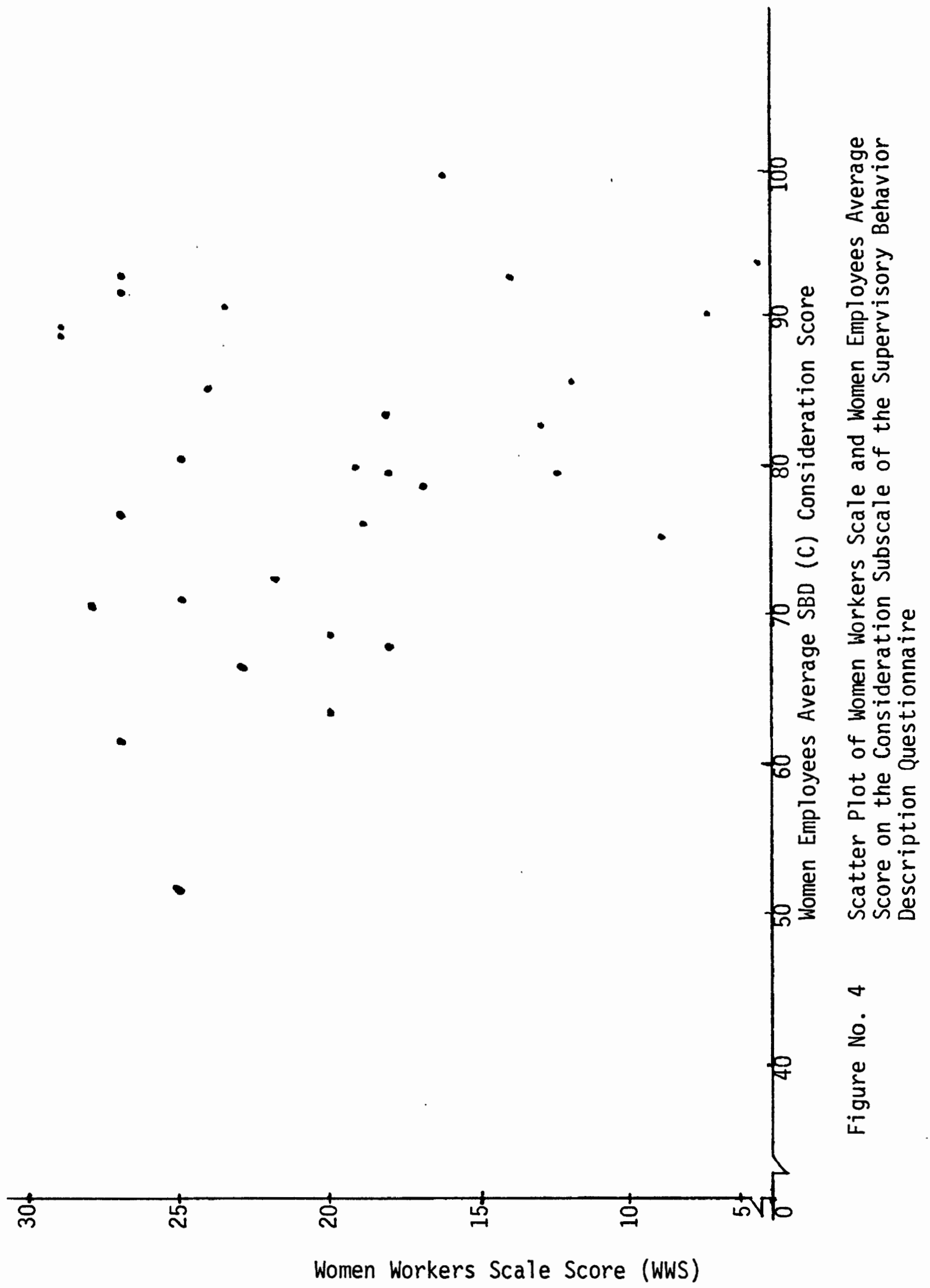

